\title{
Some Ethical Implications of Team Sports Metaphors in Politics
}

\author{
JEFFERY L. BINEHAM*
}

This essay examiñes how the use of team sports metaphors in politics calls for ethical commitments both from those to whom the metaphors are applied and from the public. The essay describes the kinds of subjects and audiences created by the use of team sports metaphors. Discourse surrounding David Stockman's offer to resign as President Reagan's Director of the Office of Management and Budget is shown to illustrate the influence of team sports metaphors in politics.

A recurring theme in recent articles refutes the classical rhetorical principle that audiences, or subjects, are autonomous. Articles by Charland (1987), Blair and Cooper (1987), Chen (1987), and Mumby (1987) demonstrate how subjects themselves are created rhetorically. This work extends Black's principle of the second persona: that discourses "imply an auditor" who can be linked to an ideology, and that this ideological persona exemplifies the kind of audience called for by the discourse. Black (1970) illustrates this principle by examining how the "cancer of communism" metaphor projects an auditor, or persona, with particular characteristics.

My concern in this paper is with how team sports metaphors in political discourse constitute subjects with a particular ethical disposition. This essay examines how team sports metaphors call for a set of allegiances and actions in political settings. My contention is that team sports metaphors establish a hierarchy and imply the necessity of commitment to that hierarchy. When an administration or other political organization utilizes team sports metaphors it calls for a particular type of audience-a sports/ spectator audience-and it calls for its members to act as team sports players. To argue this position I discuss three issues. First, I discuss briefly how metaphors in general call for ethical commitments. Second, I examine the particular kinds of commitments team sports metaphors constitute among subjects. And third, I provide a specific critical example of how team sports metaphors have functioned in a political "crisis."

\section{THE CALL OF METAPHOR}

Kenneth Burke $(1962 ; 1965)$ has argued at length that the languages people use construct hierarchical systems through which people can

\footnotetext{
* Jeffery L. Bineham is an Assistant Professor in the Department of Speech Communication at St. Cloud State University in St. Cloud, MN. Portions of this paper were presented at the Speech Communication Association Convention, 1983, and at the Central States Communication Association Convention, 1989. This research was sponsored in part by a grant from St. Cloud State University.
} 
control the mysteries and divisions of life. Because various hierarchies exist people must select the hierarchy to which they will profess loyalty and conformity. To profess such loyalty and conformity is to profess piety toward that hierarchy (1965, pp. 71-88). Once one identifies with a university department's hierarchy, for example, one is expected to embrace a pious attitude toward the norms and expectations of the department.

Several studies have demonstrated that metaphor is a trope well suited to orient people to hierarchies. Sol Worth (1974, p. 205), for instance, states that metaphorical structure helps one "to put the right things together." David Edge (1974) notes that "metaphor acts to eliminate confusion, to structure chaos" (p. 137), and that metaphor establishes and reinforces "moral and social control" (p. 142). James Fernandez (1972, p. 58) writes that people may embrace metaphors "which cause them irresistably to organize their world. . so as to facilitate or make inevitable certain scenarios." These statements indicate that metaphors structure hierarchical orders and call for piety toward those orders.

Lakoff and Johnson (1980), in their important book entitled Metapbors We Live By, argue that metaphors "create realities" for people and thus serve as "a guide for future action." People's actions will "fit" the metaphor which structures experience and this "fit" reinforces the metaphor's power "to make experience coherent" (p. 156). Michael Osborn's (1977) essay on the "archetypal sea" examines how that metaphor has symbolized the "fear of any impulse. . which threatened the serenity of a rationally managed life." Once this meaning was inferred, the metaphor could be extended to suggest that "society had to be built upon predictable, governable instincts in people" (p. 358). The sea metaphor explicitly represents a hierarchy and implicitly calls for piety toward that hierarchy. The metaphor, in other words, calls the audience to embrace pious attitudes. To use a term from Marxist cultural studies, the metaphor "interpellates" its subjects; it summons subjects to be a certain kind of people (see, for example, Hall, 1985, p. 102; and Althusser, 1970, pp. 170-177).

\section{TEAM SPORTS AS METAPHOR}

Lakoff and Johnson (1980) also assert that "the most fundamental values in a culture will be coherent with the metaphorical structure of the most fundamental concepts in the culture" (p. 22). Certainly the concept and the practice of team sports helps to structure American society in fundamental ways. Novak (1976, p. xii) states, in fact, that "the basic reality of human life is play, games, sport; these are the realities from which the basic metaphors for all that is important in the rest of life are drawn." And Duncan (1983, p. 29) asserts that "spectator sport generates literature, song, myth, and provides legitimating metaphors and authority figures for many areas of public life." The influence of team sports on our culture is far reaching and cannot be overestimated. In this section of the paper I examine the kind of commitments team sports metaphors might constitute among subjects. 
Participants in a team sport must embody certain characteristics. Sport is said to encourage traits such as "loyalty, discipline, commitment, a concern for excellence, and a "never-say-die' attitude" (Simm, 1985, p. 17). Wilbert Leonard, a sociologist, argues that athletes tend to be "less questioning and critical of authority structures" than non-athletes, and that coaches are more "organized," 'ordered," and adverse to change than noncoaches (1980, pp. 100, 102). Team players, then, must subordinate themselves to a hierarchy and recognize that the good of the organization is primary. Team sports metaphors suggests a certain hierarchical structure: head coach-assistants-players.

The team ethic also prescribes that members publicly display "absolute devotion and commitment toward the team" and that they never "concede defeat until a game or series is completed" (Kruse, 1981, p. 284). These devotions are characteristics of piety. Team members are called to affirm their dedication to the team's ultimate goal. The use of team sports metaphors suggests definite expectations from those to whom they are applied.

Evidence for this contention can be found in the world of sport itself. When Pete Rose left Cincinnati to play for the Philadelphia Phillies he was criticized severely for failure to remain devoted to his team. When Tony Dorsett missed a Dallas Cowboys practice session in 1978 he was benched for a failure to value the team over individual concerns. Both players delivered apologetic responses to affirm their pious commitment to team hierarchies and to defend their characters against ethical attack (Kruse, 1981, pp. 275-276). In 1988 a fight between Minnesota Twins Dan Gladden and Steve Lombardozzi was followed by public assurances that team unity and performance would not be disrupted. And of course the New York Mets' constant stream of squabbles is followed consistently by statements which deny any ill effects to the team. That attention is paid to such incidences indicates the expectations of ethical commitments from team members.

But perhaps more important than the commitments called for from team members is the kind of audience constituted by team sports metaphors. Team sports metaphors entice publics to perceive themselves as spectators and fans. The trademark of spectators and fans, according to sports sociologists, is not that they observe teams in action, but that they participate vicariously with their team as it performs (Novak, 1976, p. 144). This trademark is most evident in the popular "illusion that one's own presence contributes to the team's victory" (Duncan, 1983, p. 31). Not only do fans simulate playing on the team or devising strategies for action, but they immerse themselves vicariously in the contest (Spinrad, 1981). Somehow, for Dallas fans, the Cowboys stand a better chance of victory if they view from the stands or perch themselves before the television on Sunday.

The fans' participation is unique, however, as they stand in a particularly safe relationship to the game. Their combat is vicarious. It is embodied 
in a series of rituals and ceremonies which secure their commitment and loyalty, and demonstrate their pious attitudes toward the team hierarchy. Team sports and their metaphors offer fans "a feeling of continuity, resolution, and closure which rarely occurs in everyday working life" (Duncan, 1983 , p. 32). And in politics those metaphors embody "establishment values and beliefs" (p. 34). The metaphors constitute an audience of spectators who stand in a positive relationship to a conservative status quo. I next examine the influence of such metaphors in a specific political situation.

\section{THE DAVID STOCKMAN CASE}

On November 10, 1981, Office of Management and Budget Director David Stockman warned a presidential aide of a profile which would appear in the December issue of The Atlantic Montbly. "I think you'd better see this," Stockman stated. President Reagan's reading of William Greider's "The Education of David Stockman" left him "furious," especially Stockman's description of the Kemp-Roth tax plan as a "Trojan Horse" to lower the tax rate for the upper income bracket, and he called for a meeting with Stockman on November 12. By meeting time the situation had escalated so that Stockman felt compelled to offer his resignation. Reagan refused to accept the offer. Stockman explained his remarks in a press conference that afternoon and by month's end the crisis had passed (Magnuson, 1981).

Critical examination of how team sports metaphors helped to structure this political situation can illumine the rhetorical dimensions of the situation. The Reagan administration called public attention tô its pervasive use of team sports metaphors in several ways. Reagan was more apt than most presidents before him to place nationally televised telephone calls to champions in baseball, football, and basketball, and to entertain those same championship teams at the White House. These practices, if nothing else, provided the symbolic resources necessary for the public to forge a vivid connection between team sports and the administration. Further, Reagan's consistent reference to his administration as "team players" paralleled the descriptions proffered by his cabinet and by the press.

In covering the Stockman issue, for example, The New York Times stated that the President viewed Stockman "as essential to [his] 'team' " (Smith, 1981, p. 1) and that Stockman was a "chastened team player" (Cowen, 1981, p. 39). Reagan rejected Stockman's resignation because "the budget director was too valuable a member of his team" (Weisman, 1981, p. 1). An administration official stated Stockman was "needed as a member of the President's team" ("Transcript," 1981, p. 38). Newsweek (Morganthau, 1981, p. 40) described Stockman's campaign to eliminate the federal deficit as "a bitter intramural battle." And on the day the story broke Stockman himself received a birthday present from Treasury Secretary Donald Regan: a shirt with the words "I am a team player" embossed on its front (Morganthau, 1981, p. 40). 
Some who defended Stockman used team sports metaphors. Senate Majority Leader Howard Baker did not question Stockman's qualifications or commitments, but he expressed concern that the Democrats would "have a field day" with Stockman's statements and that they would "get a free shot" at the Republican party because of the Atlantic Montbly article (Lescaze, 1981, p. A3). Stockman's confusion about when the article would be published was attributed to a misunderstanding of his agreement with Greider that "the particulars of these conversations were not to be reported until . . after the season's battles were over" ("Stockman," 1981 , p. 14). A Stockman aid stated the problem stemmed from confusion "over the ground rules" regulating the use of quotations ("Stockman," 1981, p. 14).

Stockman's discourse also reveals an obvious identification with the structure of team sports metaphors. During his press conference Stockman stated that "the President asked me to stay on the team" ("Transcript," 1981 , p. 38). Several of the metaphors recorded in Greider's (1981) article are team sports metaphors. Stockman stated of Agriculture Secretary John Block, "He's on the central team" (p. 35). His tax plan "covers all [the] bases" (p. 36), Stockman said, and the process of vote trading is "that kind of game" (p. 47) without which "you can't win" (p. 52). Because Stockman's terminology is structured after the team sports metaphors which helped to define public perception of the Reagan administration, that terminology implies commitment to shared motives and goals. His discourse suggests an identification with the team's hierarchy and affirms his piety toward the team.

Stockman used the "Trojan Horse" metaphor in his description of how a supply side economic theory might be enacted. The key to supply side theory, according to Stockman, is lowering the tax rate for the upper income bracket by twenty percent. "In order to make this palatable as a political matter," he stated, "you had to bring down all the brackets [which is what the Kemp-Roth plan calls for]. But... Kemp-Roth was always a Troian Horse to bring down the top rate." (Greider, 1981, p. 46). The metaphor, a literary symbol of trickery and deception, implied that those in the lower brackets were being deceived into sacrificing for those in the higher brackets.

The statement that Kemp-Roth was a Trojan Horse violated two requirements of the team sports ethic necessary to maintain piety: 1) always display absolute devotion and commitment to the team; and 2) never concede defeat until the competition is completed. These two requirements, of course, are sometimes connected. So Stockman's apparent concession of defeat - the implication that he no longer believed in Reagan's planindicated a lack of commitment to the team's goal. When such a disruption occurs in sports, Kruse (1981, p. 283) notes, the responsible party must "assure the fans that equilibrium has been restored, and a stable relationship exists." When sports figures deliver such assurances, Kruse (p. 281) finds that they typically express sorrow and regret at having demeaned the team, and that they "tend to be brief and general." 
Stockman's response exemplifies each of these conventions. On the morning of his press conference Stockman told Republican leaders that he was "shocked and horrified" by the article and said, "I regret that I ever had the interviews" (Morganthau, 1981, p. 41). In the press conference he stated, "I deeply regret any harm that has been done" " Transcript," 1981, p. 38). His expressions of regret indicate his commitment to the team. Stockman's brief response to questions concerning the Trojan Horse metaphor is characteristic of the second convention described by Kruse. "I can only say that it was a rotten, horrible, unfortunate metaphor," he said. "I will not go into literary history to determine its meaning and application" ("Transcript," 1981, p. 38). Stockman's response, then, takes a form similar to that exhibited by actual sports figures who find themselves in similar predicaments.

\section{ETHICAL IMPLICATIONS OF THE STOCKMAN CASE}

The general structure of team sports metaphors helps to explain both the public's orientation to this situation, and the form of Stockman's response. I have not, however, explained the success of Stockman's response. While the preceding section assesses some of the ethical implications of teams sports metaphors for both "players" and "spectators," the two specific implications for "players" are most evident in this particular case, and therefore are employed most helpfully to explain the outcome of the Stockman case. The outcome of the Stockman case, then, can best be explained with reference to, first, the commitment to win at nearly any cost, and second, the commitment to the good of the team. These two specific ethical implications help to explain how team sports metaphors enabled Stockman to use and abandon the Trojan Horse metaphor.

Stockman's successful response to this situation (i.e. his ability to maintain his status as a "team player") is best explained, ironically, by two of the very standards which he was initially judged to have violated. Kruse (1981, p. 279) notes that "within the world of team sport, deeds that may appear to be morally reprehensible are sometimes tolerated and may even be encouraged when they are undertaken for the good of the team." Kruse argues further that players accused of immoral conduct or of cheating by the media and other teams' followers may actually go uncriticized by those who follow their own team. Though Stockman was required to apologize, especially for the Trojan Horse metaphor, the motive for the use of that metaphor, much like the motive for the use of the Trojan Horse itself, is easily explained: win at any cost. Stockman regretted his use of the metaphor, but he noted that The Atlantic Montbly article attributed nothing to him that he had not previously stated in public. "Almost anything other than maybe an indiscreet quotation or expression or metaphor that was contained in that article," he stated, "basically reflects things that I had been saying in our private deliberations as well as in Public comments over the last nine months" ("Transcript," 1981, p. 38). Stockman clearly 
perceived his ideas to be consistent with the Reagan Administration's game plan. His effort was simply to win. That Republican leaders remained optimistic about Stockman's future indicates that they too defined his gaffe as a forgivable statement made in the context of his effort to win the congressional battle for supply-side economic policies.

While Stockman's use of the Trojan Horse metaphor can be explained as an effort to "win at any cost," his abandonment of that metaphor can be explained as an effort to restore the public's perception of the Administration as a loyal and committed group of team players. Duncan (1983, p. 34) notes that sport expresses "a value structure in keeping with the "common good." "And as I noted earlier in the paper, sport encourages a sense of order and obedience, and thereby functions as a source of commitment and social solidarity. Stockman was faced with a unique difficulty: his statements were forgivable as efforts to win, but his image as a committed team player needed repair. Several reports indicated that Stockman sought to "draw all blame to himself" (e.g., Lescaze, 1981, p. A1), and headlines described him as "contrite" and "apologetic." Stockman's response integrated him back into the Reagan team. He was a "chastened team player," but he was still a team p1ayer. His regret for the metaphor and his direct acceptance of responsibility for its implications secured his status as a committed team player, and reassured the public that the team as a whole was united behind Reagan's policies.

The metaphors of David Stockman's education have instructive rhetorical significance. Team sports metaphors certainly are not unusual in politics. Much of Stockman's discourse, consequently, does not appear to be unusual or noteworthy. Scholars need to pay more attention, however, to the ways in which these metaphors constitute subjects with a particular range of expectations. The requirements of team members were incumbent upon the members of Reagan's administration, and that surely explains somewhat the manner in which this situation developed. But the public also seemed to be structured in a specific manner-as spectators and fans. They stood in a position whereby it seems likely that the type of response rendered by Stockman made sense, and that the primacy of team unity, invoked by the administration's team sports metaphor, made Stockman's resignation unlikely.

\section{REFERENCES}

Althusser, L. (1970). Lenin and Pbilosophy, New York: Basic Books.

Black, E. (1970). The second persona. Quarterly Journal of Speech, 56, 109-119.

Blair, C., and Cooper, M. (1987). The humanist turn in Foucault's rhetoric of inquiry. Quarterly Journal of Speech, 73, 151-171.

Burke, K. (1962). A rbetoric of motives. Berkeley: University of California.

Burke, K. (1965). Permanence and change. Berkeley: University of California.

Charland, M. (1987). Constitutive rhetoric: The case of Peuple Quebecois. Quarterly Journal of Speech, 73, 133-150.

Chen, K. H. (1987). Beyond truth and method: On misreading Gradamer's praxical hermeneutics. Quarterly Journal of Speech, 73, 183-199. 
Condit, C. M. (1987). Crafting virtue: The rhetorical construction of public morality. Quarterly Journal of Speech, 73, 79-97.

Cowen, E. (1981, Nov. 13). Chastened team player. The New York Times, p. 39.

Duncan, M. C. (1983). The symbolic dimensions of spectator sport. Quest, 35, 29-36.

Edge, D. (1974). Technological metaphor and social control. New Literary History, 6, 135-147.

Fernandez, J. W. (1972). Persuasion and performances: Of the beast in everybody ... and the metaphors of everyman. Daedalus, 101, 39-60.

Greider, W. (1981, Dec.). The education of David Stockman. The Allantic Monthly, pp. 27-54.

Hall, S. (1985). Signification, representation, ideology: Althusser, and the post-structuralist debates. Critical Studies in Mass Communication, 2, 91-114.

Kruse, N. W. (1981). Apologia in team sport. Quarterly Journal of Speech, 67, 270-283.

Lakoff, G., and Johnson, M. (1980). Metaphors we live by. Chicago: University of Chicago.

Leonard, W. M. (1980). A sociological perspective of sport. Minneapolis: Burgess Publishing.

Lescaze, L. (1981, Nov. 13). Reagan rejects Stockman offer to quit. The Washington Post, pp. A1, A3.

Magnuson, E. (1981, Nov. 23). A visit to the woodshed. Time, pp. 10-13.

Morganthau, T. (1981, Nov, 23). Et tu, David Stockman. Newsweek, pp. 40-43.

Mumby, D. K. (1987). The political function of narrative in organizations. Communication Monographs, 54, 113-127.

Novak, M. (1976). The joy of sports. New York: Basic Books.

Osborn, M. (1977). The evolution of the archetypal sea in rhetoric and poetic. Quarterly Journal of Speech, 63, 347-363.

Simon, R. L. (1985). Sports and social values. Englewood Cliffs, NJ: Prentice-Hall.

Smith, H. (1981, Nov. 13). Political risk by President. The New York Times, pp. 1, 39.

Spinrad, W. (1981). The function of spectator sports. In G. R. F. Luschen \& G. H. Sage (Eds.), Handbook of social science of sport (pp. 354-365). Chicago: Stipes Publishing.

Stockman flap raises question of ethics. (1981, Nov. 15). The Indianapolis Star, p. 14.

Transcript of Stockman's statement and news conference. (1981, Nov. 13). The New York Times, p. 38.

Weisman, S. R. (1981, Nov. 13). Stockman offers Reagan "regrets." The New York Times, pp. $1,38$.

Worth, S. (1974). Seeing metaphor as caricature. New Literary History, 6, 195-209. 
Copyright of Communication Reports is the property of Western States Communication Association and its content may not be copied or emailed to multiple sites or posted to a listserv without the copyright holder's express written permission. However, users may print, download, or email articles for individual use. 